\title{
Piłka nożna i rekonstrukcje niemieckiej tożsamości narodowej
}

KEY WORDS

football, Germany, national identity, national style of play

\begin{abstract}
Melosik Zbyszko, Piłka nożna i rekonstrukcje niemieckiej tożsamości narodowej [Football and Reconstructions of German National Identity]. Kultura - Społeczeństwo - Edukacja nr 2(10) 2016, Poznań 2016, pp. 23-33, Adam Mickiewicz University Press. ISSN 2300-0422. DOI 10.14746/kse.2016.10.2.

The article is aimed at analysing the relationship between football and ways of reconstructing the German national identity. At the beginning the origin of football in Germany is decribed. Than the role of "Berno Miracle" (German world championship in 1954) in creation the postwar new German identity is considered as well as the role of football in presenting "new Germany" to the world in the 2006 world championship organized by Germany. At the end the stereotypes considering the connections between German style of play and German „national character" are presented.
\end{abstract}

Geneza powstania i rozwoju (oraz popularności) piłki nożnej w poszczególnych krajach jest $\mathrm{w}$ sposób oczywisty związana $\mathrm{z}$ typowymi dla nich, niekiedy bardzo partykularnymi warunkami społeczno-kulturowymi. I tak na przykład w przypadku Brazylii i Argentyny główną rolę odegrały tutaj wpływy brytyjskie, inkorporowane przez lokalne tradycje i kulturę (Melosik, 2016: 253-263). Z kolei w Japonii najbardziej nośnym czynnikiem rozwoju tej dyscypliny było uznanie jej za jeden $\mathrm{z}$ komponentów zdobycia przez ten kraj ważnej roli $\mathrm{w}$ globalnym świecie (por. Melosik, 2015: 313-326).

Niemiecka piłkarska drużyna narodowa stanowi obecnie absolutną potęgę, podobnie jak i niemieckie drużyny klubowe, czego dowodem są rozliczne efektowne zwycięstwa i sukcesy w prestiżowych turniejach (ich symboliczną egzemplifikacją może być odniesione w finale Mistrzostw Świata w Brazylii w 2014 zwycięstwo na słynnej Maracanie nad gospodarzami aż 7:1). W kontekście 
współczesnych sukcesów trudno byłoby założyć, że geneza niemieckiej piłki nożnej wiązała się $\mathrm{z}$ poważnymi społeczno-ideologicznymi kontrowersjami. A jednak tak $w$ istocie było.

Piłka nożna wzbudziła zainteresowanie w Niemczech w ostatnich dwóch dekadach dziewiętnastego wieku - pod wpływem wzorów angielskich (w trakcie pierwszych meczów wprowadzano także ciekawe regulacje, i tak na przykład w roku 1896 zdefiniowano, że „boisko do piłki nożnej musi być oczyszczone z drzew i krzewów" - Markovits, Rensmann, 2010: 58). Przy tym, jak ujmuje to Udo Merkel:

Na początku sport ten spotkał się z obojętnością, która jednak wkrótce przekształciła się we wrogość. Wpływowi członkowie narodowego ruchu gimnastycznego Turnbewegung próbowali zablokować upowszechnianie się tego sportu. Określali go mianem „angielskiej choroby" i stwierdzali, że jest to (...) sport nie-niemiecki, trywialny, pozbawiony metafizycznej podbudowy, a stąd dekadencki. (Merkel, 2014: 241)

Konserwatywne sektory klasy średniej widziały w piłce nożnej zagrożenie dla dominującej wówczas w Niemczech gimnastyki. Piłka nożna stanowiła dla nich integralną część negatywnie postrzeganej „zachodniej cywilizacji” - w przeciwstawieniu do tradycyjnej niemieckiej „Kultury” (Merkel, 2014: 241) (w bawarskich szkołach gra w piłkę nożną była zabroniona aż do roku 1913 - Koller, Brändle, 2015: 34).

Jednak „wbrew ogromnemu oporowi ze strony elit kulturowych i zwolenników gimnastyki, piłka nożna stawała się coraz atrakcyjniejsza, na początku dla niemieckiej klasy średniej, a potem klasy pracującej” (Markovits, Rensmann, 2010: 58). Społeczno-ekonomiczne zmiany w Niemczech, a w szczególności proces urbanizacji i „fragmentaryzacji codzienności”, przyniosły zmiany w stylu życia. W ich konsekwencji, jak ujmuje to Udo Merkel, ,uprawianie ortodoksyjnej gimnastyki nie spełniało już potrzeb fizycznych i psychicznych". Nowe warunki życia powodowały wzrost znaczenia tych dyscyplin sportowych, które rozgrywano „na zewnątrz”, na świeżym powietrzu, a nie w halach sportowych. W konsekwencji coraz więcej młodych ludzi z klasy średniej zaczęło uprawiać ten sport (Merkel, 2014: 242). Po roku 1920 piłka nożna ostatecznie przestała być sportem klasy średniej, zaczęła być dominowana przez klasę pracującą - szczególnie w rejonach bardzo zindustrializowanych i zaludnionych, takich jak Zagłębie Ruhry, gdzie powstały wówczas słynne i znaczące do dzisiaj kluby - Borussia Dortmund i Schalke 04 Gelsenkirchen (Merkel, 2014: 242). Niemiecka piłka nożna rozwijała się dynamiczna aż do początków II wojny światowej.

Po wojnie alianci zezwolili na powstanie pięciu lig regionalnych (których zwycięzcy walczyli o prymat krajowy), a pierwszy sezon ogólnoniemieckiej Bundesligi miał miejsce dopiero $\mathrm{w}$ sezonie 1963/1964 (Merkel, 2007: 226) 
(osobne rozgrywki miały miejsce w socjalistycznej Niemieckiej Republice Demokratycznej).

Przełomem we współczesnej historii niemieckiej piłki nożnej były mistrzostwa świata w szwajcarskim Bernie w roku 1954 - kiedy to Niemcy zdobyli tytuł mistrza świata po całkowicie nieoczekiwanym zwycięstwie $\mathrm{w}$ finale $\mathrm{z}$ faworyzowanymi Węgrami $3: 2$ (z którymi w fazie grupowej przegrały $3: 8$ ). Mistrzostwa te odegrały ogromną rolę $\mathrm{w}$ procesie kreowania powojennego odrodzonego narodu niemieckiego. Zdaniem Wernera Kraussa „cud w Bernie” w 1954 roku wyznaczył „początek epoki nowych narodzin Niemiec jako narodu posiadającego coraz większe poczucie własnej wartości; pojawiło się wówczas kolektywne poczucie "my« i idea "narodowej tożsamości «" (Krauss, 2003: 197-2161). Zwycięstwo w Bernie dało, według niektórych komentatorów „prawdziwy początek Republice Federalnej Niemiec po 1945 roku”. Uważano, że stanowiło ono część nieuchronnego procesu, w którym na arenie międzynarodowej Niemcy „muszą być na nowo brane poważnie pod uwagę" (Van Ours, Van Tuijl, 2010: 4). Stało się jednym najbardziej z najbardziej istotnych mitów powojennych Niemiec (Daffner, 2011: 98-99).

Po zwycięstwie w Bernie niemieckie elity społeczne zaczęły nadawać piłce nożnej ogromne znaczenie jako bardzo spektakularnej ekspresji narodowości oraz płaszczyzny zaprezentowania się światu. Postrzegano ten sukces także jako wyraz i potwierdzenie rozwoju społeczno-ekonomicznego (słynnego „cudu gospodarczego"), który miał wówczas miejsce w Niemczech. Sukces w mistrzostwach świata zmienił, jak już sygnalizowano, sposób myślenia o narodzie niemieckim. W trakcie meczów w Bernie niemieccy kibice śpiewali „Deutschland, Deutschland über alles”, a niemieckie czasopismo „Bild” opublikowało swój główny artykuł na pierwszej stronie pod tytułem „Jesteśmy znowu wielcy”. Ponadto, wydarzenia to dało Niemcom impuls do ponownego doceniania, czy wręcz uwielbiania, swoich bohaterów narodowych (nie było to możliwe w latach po drugiej wojnie światowej), a symbolem tego może być także nazywanie w latach siedemdziesiątych znakomitego piłkarza Franza Beckenbauera „Kaiserem" (cesarzem) (Crolley, Hand, 2006: 70).

Warto dodać, że po powrocie do Niemiec zwycięską drużynę przywitało w Monachium pół miliona ludzi, w Kaiserlauten - 100 tysięcy, w Düsseldorfie 200 tysięcy. „Po raz pierwszy po ukończeniu drugiej wojny światowej Niemcy odczuwali prawdziwą [narodową] dumę i przynależność, ale przede wszystkim, nie wahali się tego publicznie wykazywać" (Merkel, 2007: 228).

W swoich analizach rosnącej roli piłki nożnej w społeczeństwie niemieckim Wolfram Pyta wychodzi z założenia, że ma ona „kulturowo twórczą moc”, która

\footnotetext{
${ }^{1} \mathrm{~W}$ artykule skorzystano z wersji tego tekstu, która ukazała się pod adresem internetowym http://wkrauss.eu/dokumente/PDFfiles/2003_German_Miracles_final_draft.pdf, s. 3, dostęp: 4.12.2016.
} 
może „rozkwitać w pewnych warunkach historycznych” (Pyta, 2006: 1). Uważa on, że nadzwyczajne znaczenie kulturowe piłki nożnej we współczesnych Niemczech wynika z sytuacji społeczno-politycznej w tym kraju po drugiej wojnie światowej (Pyta, 2006: 2). Wolfram Pyta uważa, że narodowa piłka nożna stanowiła w powojennych Niemczech antidotum na "symboliczną dewastację", która odnosiła się wówczas do wizerunku Niemców we własnych oczach i do procesu odtwarzania społeczności (Pyta, 2006: 2). Po wojnie światowej wszystkie zwykle istniejące formy ideologii narodowej, które stanowią zwykle podstawę tworzenia tożsamości narodowej, były w Niemczech - z uwagi na ich potencjalny związek z przeszłością - z góry kwestionowane (Pyta, 2006: 8). Odrzucano także - w tym powojennym okresie - takie pojęcia, jak niemiecki „duch narodowy” i „niemiecka tożsamość" (Bonzel, 2006: 1).

W latach pięćdziesiątych Niemcy nie rozwinęli więc jeszcze - niezwiązanych z nacjonalistyczną przeszłością - symboli i rytuałów narodowych. Historyk Robert Moeller stwierdził: po roku 1945 ich głównym problemem było „ustanowienie poczucia kolektywności, które nie wywodziłoby się z nacjonalistycznej retoryki skażonej związkami z nazizmem" (Bonzel, 2006: 3). Powtórzę raz jeszcze za Wolframem Pytą: zwycięstwo niemieckich outsiderów nad perfekcyjną drużyną Węgier w Bernie w roku 1954 (która rok wcześniej wygrała na Wembley z niepokonaną tam od 90 lat Anglią) stało się symboliczne - w procesie budowania tożsamości narodowej (Pyta, 2006: 9). Ówczesny Minister Spraw Wewnętrznych Gerhard Schröder stwierdził, odwołując się do idei koniecznego powojennego odtwarzania niemieckiej tożsamości:

(...) Nasze zwycięstwo w Bernie wywarło na nas ogromny wpływ. Nie mamy [obecnie] takich narodowych wydarzeń i symboli, które dostarczałyby pogłębionych kolektywnych doświadczenie, jakie mają inne narody. Doceniamy wiec każde takie wydarzenie, które pośredniczy w tworzeniu naszego wspólnego poczucia tożsamości. (Pyta, 2006: 13)

Poza tym, po roku 1954 te same cechy charakteru narodowego, które dla nazistów były istotą militaryzmu i mocarstwowej polityki, zaczęto umieszczać w akceptowalnym kontekście sportowym. Zdobycie tytułu mistrzów świata spowodowało, że - jak piszą Liz Crolley i David Hand - „Niemcy znowu mogli być dumni ze swojej reputacji, której sednem było zdyscyplinowanie, orientacja na kolektywny wysiłek, pracowitość i bardzo skoncentrowana, wręcz bezwzględna efektywność”. „Wartości, które zostały skompromitowane przez rządy nazistów, odnalazły teraz swoje nowe miejsce w świecie piłki nożnej" (Crolley, Hand, 2002: 71). I w praktyce, jak zauważa się niekiedy, to nie proces norymberski czy ustanowienie RFN w roku 1949, lecz właśnie zwycięstwo w Bernie „reprezentowało emocjonalnie i psychologicznie koniec drugiej wojny światowej”. Zwycięstwo to stanowiło podstawę stworzenia legendy, której potrzebuje każdy naród (Crolley, 
Hand, 2002: 71). Stało się źródłem „kolektywnego emocjonalnego doświadczenia, które mogło połączyć ludność Zachodnich Niemiec w jedną społeczność” (Bonzel, 2006: 3). Zwycięstwo w Bernie w 1954 pozwoliło na „stworzenie popularnego mitu, który mógłby głęboko zakorzenić się w niemieckiej kolektywnej wyobraźni”. Ponadto, "pozwoliło to na upolitycznienie sukcesu sportowego", w kontekście akceptacji młodego państwa, zarówno na forum wewnętrznym, jak i na arenie międzynarodowej. Miało to miejsce na płaszczyźnie sportowej, która pozornie jest „apolityczna”, a ponowne wejście na świat miało miejsce w „cywilizowany sposób”. Wizerunki piłkarzy nie odwoływały się do mitów militarnych bezwzględnych "teutońskich Zygfrydów”, ale do idei zwykłych, dbających o rodzinę Niemców. Zwycięstwo zwiększyło więc poczucie własnej wartości Niemców i stanowiło jedną z podstaw tworzenia nowego systemu wartości (Bonzel, 2006: 4).

Również i w następnych pełnych sukcesów dekadach niemiecka piłka nożna krystalizowała wręcz - aby odwołać się do uwag Alana Tomlinsona i Christophera Younga - dyskusje w kwestii „tożsamości narodowej i sposobu, w jaki koncepcje i stereotypy odnoszące się do charakteru narodowego są konstruowane i reprezentowane" (Tomlinson, Young, 2006: XIII). Można tutaj przywołać wybrane konteksty rozgrywanych w Niemczech mistrzostw świata w piłce nożnej w roku 2006. Stanowiły one, zdaniem wielu komentatorów, kolejny przełom w reinterpretacji narodu niemieckiego w świecie. Powstała wówczas idea „nowego patriotyzmu niemieckiego", związana z kolejną udaną próbą wymazania ciągle istniejących dwuznaczności podczas eksponowania niemieckiego hymnu i niemieckiej flagi. Mistrzostwa $\mathrm{z}$ roku 2006 były płaszczyzną tworzenia wizerun$\mathrm{ku}$ „zupełnie nowych Niemiec”, a narodowa drużyna niemiecka stanowiła dla części społeczeństwa niemieckiego „wyidealizowany konstrukt wyimaginowanej niemieckiej społeczności” (Daffner, 2011: 100). Tak skomentował tę sytuację znakomity niemiecki piłkarz Oliver Bierhoff: „W roku 2006 śpiewanie narodowego hymnu i wymachiwanie flagą stało się normalne, dawało radość, a przecież nie tak dawno jeszcze większość starała się trzymać na stadionie jak najdalej od tych, którzy śpiewali hymn" (Honigstein, 2015: 274).

Z kolei rząd niemiecki po sukcesie mistrzostw świata w roku $2006 \mathrm{w}$ specjalnym raporcie stwierdził: „Nawet w krajach, w których tradycyjnie postrzegano Niemcy w sposób krytyczny, dawne stereotypy zostały podważone podczas mistrzostw świata. Obecnie mówi się, że Niemcy i naród niemiecki są w dużym stopniu zrelaksowane, przyjacielskie i emocjonalne" (Brand, Niemann, 2014: 48). Nie ulega więc wątpliwości, że mistrzostwa świata w Niemczech w roku 2006 przyczyniły się do zmiany politycznego obrazu tego kraju na świecie. Zdaniem Udo Merkela, „pokazały one, że Niemcy uwielbiają się bawić, że istnieje hedonistyczna strona ich charakteru”; poza tym "Niemcy zaprezentowały się światu jako przekonany o swojej wartości, kreatywny i wielokulturowy gospodarz" (Merkel, 2013: 33). 
Ponadto kierowana wówczas przez Jűrgena Klinsmanna narodowa reprezentacja Niemiec zrezygnowała $\mathrm{z}$,mało inspirującego, nudnego i wyrachowanego, zorientowanego wyłącznie na zwycięstwo stylu gry, który w przeszłości odzwierciedlał wizerunek tego kraju”. „Nowy, atrakcyjniejszy (...) styl odzwierciedlał głębszą zmianę, a w szczególności odkrycie zdrowego, odwołującego się do wysokiej samooceny niezagrażającego nikomu patriotyzmu”. Miliony niemieckich flag pojawiły się na ulicach miast, samochodach, rowerach. Młodzi ludzie malowali twarze $\mathrm{w}$ kolorach niemieckich barw narodowych. Trzeba wspomnieć raz jeszcze, że „W przeszłości takie spontaniczne prezentowanie narodowych uczuć i patriotyzmu (...) wywoływałoby (...) oburzenie i złość, przypominając Niemcom ich nazistowską przeszłość" (Merkel, 2013: 34).

Sanna Inthorn wskazuje na fakt, iż niemieckie media konstruowały tożsamość narodu niemieckiego na mistrzostwach świata i mistrzostwach Europy w latach 1998, 2000, 2002, 2004 - głównym motywem była niemiecka kultura i niemiecki charakter (Inthorn, 2007: 97). Istniało przy tym przekonanie, że funkcjonuje naturalny zestaw niemieckich narodowych wartości i tradycji, które drużyna narodowa reprezentuje, a widownia akceptuje (Inthorn, 2007: 103).

Polityczne (i to negatywne w swojej istocie) konteksty meczów Niemców z niektórymi drużynami europejskimi są jednak nadal aktualne. I tak na przykład twierdzi się, że mecze Anglii z Niemcami wywołują wśród kibiców angielskich natychmiastową „esencjalizację angielskiej narodowej tożsamości” (Brand, Niemann, 2014: 45). Anglicy zdają się nagle krystalizować swoją tożsamość $\mathrm{w}$ „negatywnym ostrzu” skierowanym przeciwko Niemcom. Mecze piłkarskie Anglii z Niemcami wzbudzają też ogromne nastroje germanofobii w prasie brytyjskiej i przypomnienie wydarzeń $\mathrm{z}$ historii. $\mathrm{W}$ dniach poprzedzających mecze ma się też wrażenie, że dla wielu Anglików historia Niemiec mieści się między latami 1933-1945 (Beck, 2003: 407).

Podczas mistrzostw świata $\mathrm{w}$ roku 1990 przed meczem Anglia-Niemcy w półfinale pisano: „Pokonaliśmy ich w roku 1945. Pokonaliśmy ich w roku 1966 [w finale mistrzostw świata], teraz walka w 1990" (Anglicy ten mecz przegrali). Mistrzostwa Europy w 1996 w Anglii wzbudziły w prasie angielskiej zdecydowanie szowinistyczne nastroje. „Daily Mirror” przywołał początek II wojny światowej na swojej czołówce: „Achtung! Jesteście otoczeni. Dla ciebie Fritz mistrzostwa Europy w 1996 są zakończone" (Beck, 2003: 401) (Niemcy wygrali tam z Anglią w półfinale w rzutach karnych). Podczas tych samych mistrzostw brytyjska prasa, pisząc o Niemcach, używała metafor odwołujących się do przeszłości; gracze niemieccy określani byli nie tylko mianem "arogantów”, ale także "najeźdźców”, którzy przygotowują na boisku „zasadzki” i „przegrupowują się”. A piłkarz Jürgen Klinsmann określany był mianem niemieckiego „szturmowca”, który pomoże Niemcom podbić Europę (Crolley, Hand, Jeutter, 2000: 111). 
W październiku 2000 w brytyjskim „Time” napisano: „Dla Anglików Niemcy są najstarszym wrogiem. Mecze z nimi mają większe znaczenie niż z kimkolwiek innym. Duchy historii i historia piłki nożnej spotykają się na boisku" (Beck, 2003: 408).

Z kolei międzynarodowa piłkarska konfrontacja z Niemcami odgrywała szczególną rolę $\mathrm{w}$ "globalnym nacjonalizmie" holenderskim. W Holandii mecze z Niemcami przywołują ciągle wspomnienia II wojny światowej, a piłkarze niemieccy nie są inaczej określani, jak mianem „Szwabów” lub „Fryców”, z kolei Niemcy określają piłkarzy holenderskich pejoratywnym określeniem Cheeseheads („serogłowi”) (Brand, Niemann, 2014: 45). Holendrzy przeciwstawiali przy tym własny „olśniewający” styl gry „ponurej, mechanicznej wersji stylu, który był powszechnie przypisywany Niemcom" (Lechner, 2007: 216). Jeden z kibiców holenderskich napisał po zwycięstwie Holandii z Niemcami w meczu w roku 1988 w Hamburgu 2:1 (Holandia pokonała następnie w finale Związek Radziecki), w półfinale mistrzostw Europy: „Był to najpiękniejszy dzień mojego życia”. 9 milionów z 16 milionów Holendrów wyszło na ulice, aby świętować to zwycięstwo (Van Houtum, Van Dam, 2002: 243). Mecz ten uważany był także za rewanż za porażkę z Niemcami w 1974 roku w finale mistrzostw świata w Niemczech przez słynną drużynę totalnego futbolu; porażkę nazywaną "matką wszystkich klęsk" (Van Houtum, Van Dam, 2002: 244). Dla wielu komentatorów było zresztą niezrozumiałe, $\mathrm{w}$ jaki sposób jedna $\mathrm{z}$ najlepszych jedenastek $\mathrm{w}$ historii piłki nożnej mogła przegrać $\mathrm{w}$ finale mistrzostw świata $\mathrm{w}$ Niemcami $\mathrm{w}$ roku 1974, zdobywając bramkę z rzutu karnego w pierwszej minucie i posiadając w swoim składzie „artystę” i „geniusza” Johanna Cryufta. Simon Barnes komentował ten mecz następująco: „Metoda zwyciężyła szaleństwo: nauka pokonała sztukę: godne szacunku zwyciężyło to, co jest godne miłości” (Kraba, 2010: 100). Szok po porażce narodowego zespołu holenderskiego w finale mistrzostw świata w roku $1974 \mathrm{w}$ meczu z Niemcami był tak wielki, że Johan Timmers stwierdził: „klęska w 1974 stanowiła największą traumę w dwudziestym wieku, poza powodzią w roku 1953 i II wojną światową". Ta porażka przypomniała wielu Holendrom brutalne działania Niemców wobec ich kraju w latach II wojny światowej (Jensen, 2014: 723).

Z kolei trudno też nie przytoczyć faktu, iż w 1988 roku niemieccy kibice-naziści podczas mistrzostw świata we Francji śpiewali - w trakcie meczów swojej drużyny - piosenkę ze słowa: „raz jeszcze dokonamy inwazji na Francję” (Merkel, 2007: 234).

Kolejny kontekst zrozumienia „istoty” czy „logiki” niemieckiej piłki nożnej wiąże się z definiowaniem - zarówno w samych Niemczech, jak i na arenie międzynarodowej - relacji między stylem gry reprezentowanym przez drużyny niemieckie a niemieckim „charakterem narodowym”. 
$\mathrm{W}$ tym kontekście $\mathrm{w}$ raporcie poświęconym recepcji Niemiec na świecie stwierdzono, iż współcześnie „niemiecki football uosabia dwie pozytywne strony niemieckiego ducha - perfekcyjnie ustrukturyzowany i zdyscyplinowany porządek, ale także kreatywny, innowacyjny pragmatyzm”; "niemiecki charakter się przekształcił - $\mathrm{i}$ to jest widoczne $\mathrm{w}$ footballu niemieckim" (Germany in the Eyes, 2015: 34). Z kolei przywoływany już w tym tekście piłkarz Oliver Bierhoff stwierdził, że podczas mistrzostw w 2014 roku Niemcy stworzyli zespół „kompletny”, „łącząc w sobie indywidualizm z etosem zespołowym, bardzo nowoczesne techniczne kwalifikacje ze zdrową dawką dobrych starych niemieckich cnót" (Honigstein, 2015: 273). Gertruda Pfister twierdzi z kolei, że w Niemczech piłka nożna dostarcza „sceny, na której są demonstrowane i nagradzane takie oczekiwane od mężczyzn cechy i zachowania, jak wytrzymałość, siła i duch walki. Stadion piłkarski jest miejscem, gdzie - zarówno na boisku, jak i na trybunach mężczyźni mogą być mężczyznami i działać jak "prawdziwi mężczyźni»". Następuje tutaj, według tej samej autorki, gloryfikacja zarówno nadrzędności męskości, jak i narodowości: „Deutchland vor - noch ein Tor” („Niemcy do przodu - jeszcze jeden gol”). „Język piłki nożnej [w Niemczech] należy do świata mężczyzn, świata pełnego metafor, opisującego mecz jako walkę, a graczy jako żołnierzy i bohaterów" (Pfister, 2006: 93).

H. Kissinger pisze o tym następująco: „Niemiecka drużyna narodowa jest przygotowywana do meczu, tak jak (...) do wojny. Gra jest drobiazgowo planowana (...)". Cechuje ją „zapobiegawczość, staranne przygotowanie i ciężka praca [na boisku] (...) Jednocześnie niemiecki zespół narodowy cierpi na tę samą przypadłość, co słynny plan Schlieffena związany ze strategią przyjętą przez Niemcy podczas I wojny światowej (...). Nie można wszystkiego przewidzieć" (za: Van Ours, Van Tuijl, 2010: 7). Istnieje jednak także przekonanie, że niemieckie drużyny (podobnie jak angielskie) nie są pokonane, dopóki nie zabrzmi ostatni gwizdek sędziego. I rzeczywiście, dane wskazują, że Niemcy strzelają w ostatnich minutach ważnych meczów więcej bramek niż inne zespoły (za: Van Ours, Van Tuijl, 2010: 8). Uważa się też, że nierezygnowanie aż do „ostatniego gwizdka" są w przypadku piłkarzy niemieckich związane $\mathrm{z}$ ich narodową tożsamością (za: Van Ours, Van Tuijl, 2010: 2). W 1954 roku w finale w Bernie napastnik Helmut Rahn zdobył w meczu z Węgrami decydującą bramkę (na $3: 2$ ) w 85. minucie meczu. Z kolei w finale mistrzostw świata w roku 1990 roku niemiecki obrońca Andreas Brehme zdobył w tej samej minucie bramkę w meczu $\mathrm{z}$ Argentyną - jedyną w tym spotkaniu. W finale mistrzostw świata na Wembley w 1966 roku Niemcy wyrównali w meczu z Anglią na 2: 2 tuż przed końcowym gwizdkiem sędziego (przegrywając jednak finał po dogrywce $2: 4$ ). W przegranym po dogrywce meczu z Włochami w półfinale mistrzostw świata w roku 1970 wyrównanie dla Niemców na 1:1 (prowadzące do tej dogrywki) padło minutę 
przed końcem meczu. Z kolei w finale mistrzostw Europy, w meczu z Czechosłowacją w roku 1976 Niemcy wyrównali na $2: 2$ w ostatniej minucie, przegrywając jednak ostatecznie po rzutach karnych. W półfinale mistrzostw świata w roku 1986 Niemcy wygrały z Francją po bramce strzelonej w ostatniej minucie. Podaje się jeszcze wiele przykładów spotkań różnego typu, w których niemiecka drużyna narodowa zdobywała bramki w ostatnich minutach, zwykle na wagę zwycięstwa (za: Van Ours, Van Tuijl, 2010: 4-6).

Styl gry niemieckich drużyn jest jednak także bardzo często krytykowany. I tak w medialnych komentarzach o niemieckim futbolu pisze się: nikt nie ma szans, „kiedy teutońska maszyna zaczyna pracować”, „niemiecki tłok jest wulgarny i mechaniczny”, „regularny mechaniczny rytm, zimny jak lód i stalowy”. „Niemcy są maszyną do wygrywania. A kiedy nie wygrają, są maszyną, która przegrała. Ale zawsze są maszyną" (Crolley, Hand, 2002: 151).

Niemiecką piłkę nożną analizuje się często przez pryzmat stereotypów, przy czym, jak zauważają L. Crolley, D. Hand: „Wszystkie są prawdziwe. Wiarygodność, mechaniczność, brak polotu, nieatrakcyjne gole" (Crolley, Hand, 2002: 151). Określa się Niemców na boisku jako agresorów - „nic nie zatrzyma ich marszu”. „Niemiecka «taktyka» jest "prosta, a jej istotą jest przede wszystkim narzucanie siły fizycznej» graczom drużyny przeciwnej, ponieważ «niemieccy piłkarze myślą poprzez swoją fizyczność»”. Pokonać można ich tylko „wyobraźnią, kreatywnością, inteligencją" (Crolley, Hand, 2002: 95). W komentarzach prasowych pisze się, że niemiecki zespół narodowy „wygląda zwykle tak, jakby był wyrobiony w fabryce Porsche” - „niemiecka maszyna mieli w sposób nieubłagany" (Crolley, Hand, 2002: 50). Twierdzi się też, że zespół na boisku odzwierciedla niemieckie cechy narodowe: agresywną siłę, nudną wydajność, arogancką pewność siebie (Crolley, Hand, 2002: 161).

Dodam, że jeden z najlepszych niemieckich trenerów Ottmar Hitzfeld porównywał funkcjonowanie zespołu niemieckiego na boisku do działania doskonałego silnika samochodowego, postrzegał jednak konstruowanie go także jako „psychologicznego puzzla”: „Bayern ma wrażliwą konstrukcję, podobnie, jak silnik Ferrari”; „każdy szczegół musi być dopracowany” (Honigstein, Das Reboot, 2015: 15). Jego zespoły opierały się na ścisłej hierarchii, a przy bardzo restryktywnej realizacji poleceń. Metafora maszyny pojawia się również u Michaela Vesetha, który stwierdza: „Brazylijczycy grają w piłkę tak, jak tańczą, a Niemcy tak, jak robią samochody" (Veseth, 2010: 107).

Moje własne obserwacje meczów niemieckiej drużyny narodowej oraz najlepszych drużyn klubowych tego kraju wskazują, że niemiecki styl gry opiera się na zdyscyplinowaniu, zaangażowaniu, skuteczności i ciężkiej pracy na boisku oraz agresywności. Zespoły są bardzo dobrze zorganizowane. Większość graczy ma znakomite warunki fizyczne, które skutecznie wykorzystuje; są niezwykle 
mocno umotywowani, dobrze przygotowani technicznie i taktycznie. Starają się perfekcyjnie wypełniać przeznaczoną im przez trenera rolę i podporządkowują swoje indywidualne ambicje grze zespołowej. Niemieckie drużyny są zorientowane na atak i na nieustanną presję na przeciwnika (i mniej na typową dla latynoskiej piłki nożnej improwizację). Mecze cieszą się ogromnym zainteresowaniem ze strony kibiców, którzy entuzjastycznie dopingują swój zespół, będąc z nim niezależnie od jego sukcesów i porażek (a na stadionie panuje wspaniała atmosfera).

Na zakończenie można stwierdzić, że zarówno historia, jak i współczesność niemieckiej piłki nożnej stanowią znakomitą egzemplifikację tezy o nieuchronnych związkach sportu z polityką. Co ciekawe, $\mathrm{w}$ relacjach z polityką niemiecka piłka nożna zdołała, moim zdaniem, zachować pewną autonomię. Jest z pewnością - w wielu przypadkach - instrumentalnie upolityczniania, jednakże stanowiła ona w drugiej połowie dwudziestego wieku niezwykle istotny niezależny i bardzo nośny czynnik kształtowania nowej niemieckiej tożsamości narodowej. I ta ocena odnosi się także do pierwszych dekad nowego wieku.

\section{Literatura}

Beck P.J. (2003). The relevance of the "irrelevant”: football as a missing dimension in British relations with Germany. „International Affairs”, Vol. 79, No. 2.

Bonzel K. (2006). Soccer to the rescue: how miracle of bern gave Germans back their identity - twice, „Sporting Traditions”, Vol. 22, No. 2 (May).

Brand A., Niemann A. (2014). Football and national identity in Europe. [In:] More than a Game. Sports, Society and Politics, Panorama. Insights into Asian and European Affairs. Singapore.

Crolley L., Hand D. (2002). Football, Europe and the Press. London.

Crolley L., Hand D. (2006). Football and European Identity. Historical Narratives Through the Press. London.

Crolley L., Hand D., Jeutter R. (2000). Playing the identity card: Stereotypes in European football. „Soccer and Society”, Vol. 1, No. 2.

Daffner C. (2011). Footbal, mythology and identity in Sönke Wortmann's Deutschland. Ein sommermärchen. „Austausch”, Vol. 1, No. 1, April.

Germany in the Eyes of the World, Key findings of the second GIZ survey. (2015). s. 34. https://www.giz.de/de/downloads/giz2015-en-germany-in-the-eyes-of-the-world-2015.pdf, dostęp: 11.10.2016.

Honigstein R. (2015). Das Reboot. How German Football Reinvented Itself and Conquered the World. London.

Inthorn S. (2007). German Media and National Identity. Youngstown.

Jensen R. (2014). Looking at the extraordinary success of "Clockwork Orange”: examining the brilliance of total football played by the Netherlands. „Soccer and Society”, Vol. 15, No. 5.

Koller C., Brändle F. (2015). Goal! The Cultural and Social History of Modern Football. Washington.

Kraba M. (2010). The Story Has Been Told. Bloomington. 
Krauss W. (2003). Football, nation and idenntity: German miracles in the post-war era. [In:] N. Dyck, E.P. Archetti (eds.). Sport, Dance and Embodied Identities. Oxford.

Lechner F.J. (2007). Imagined communities in the Global Games: soccer and the development of Dutch Global Identity, „Global Networks. A Journal of International Affairs”, Vol. 7, No. 2.

Markovits A.S., Rensmann L. (2010). Gaming the World: How Sports are Reshaping Global Politics and Culture. Woodstock.

Melosik Z. (2015). Społeczno-kulturowe konstrukcje piłki nożnej: męskość, kolektywna tożsamość i japonizacja. „Studia Edukacyjne” nr 37.

Melosik Z. (2016). Piłka nożna, mulatyzm i tożsamość narodowa w Brazylii. „Studia Edukacyjne” $\mathrm{nr} 38$.

Merkel U. (2007). Milestones in the development of football fandom in Germany: global impacts on local contests. „Soccer and Society” Vol. 8, No 2-3, s. 226.

Merkel U. (2013). Footballs fans and clubs in Germany: conflicts, crises and compromises. [In:] P. Kennedy, D. Kennedy (eds.). Footballs Supporters and Commercialization of Football. Comparative Responses across Europe. Abingdon.

Merkel U. (2014) German football culture in the new millenium: ethnic diversity, flair and youth on and off the pitch. „Soccer and Society” Vol. 15, No 2.

Pfister G. (2006). The future of football is female!? On the past and present of women's football in Germany. [In:] A. Tomlinson, C. Young. German Footbal. History, Culture, Society. Abingdon.

Pyta W. (2006). German football. A cultural history. [In:] A. Tomlinson, C. Young. German Footbal. History, Culture, Society. Abingdon.

Tomlinson A., Young C. (2006). Preface. [In:] A. Tomlinson, C. Young. German Footbal. History, Culture, Society. Abingdon.

Van Houtum H., Van Dam F. (2002). Topophilia or Topoporno? Patriotic place attachment in international football derbies. „International Social Science Review” Vol. 3(2).

Van Ours J.C., Van Tuijl M.A. (2010). Country-Specific Goal-Scoring in the "Dying Seconds" of International Football Matches. "Forschungsinstitut zur Zukunft der Arbeit Institute for the Study of Labor", May 2010, IZA DP No. 4970. http://ftp.iza.org/dp4970.pdf, dostęp: 4.12.2016. Veseth M. (2010). Globaloney 2.0. The Crash of 2008 and the Future of Globalization. Plymouth. 
